\title{
4. MAGNETIC POLARITY REVERSAL STRATIGRAPHY OF HOLE 810C, SHATSKY RISE, WESTERN PACIFIC OCEAN ${ }^{1}$
}

\author{
William W. Sager, ${ }^{2}$ Evelyn L. Polgreen, ${ }^{2}$ and Frank R. Rack ${ }^{2,3}$
}

\begin{abstract}
A magnetic stratigraphy study was undertaken on Hole $810 \mathrm{C}$ cores to provide age constraints and to characterize sedimentation on the summit of Shatsky Rise. Sediments from this hole are mostly nannofossil oozes recovered by the advanced hydraulic piston corer which gave virtually complete recovery to $136 \mathrm{~m}$ below seafloor. High-resolution magnetic measurements were made aboard ship with a pass-through cryogenic magnetometer, and these results were confirmed with discrete samples also measured with a cryogenic magnetometer. The sediments give clearly defined magnetic polarity zones within the upper $100 \mathrm{~m}$ below seafloor. It was possible to make a convincing match with the polarity reversal time scale from the surface to $76.8 \mathrm{~m}$ below seafloor, through the base of the Gilbert Chron near the Pliocene/Miocene boundary. Because of slow sedimentation and hiatuses punctuating the middle to upper Miocene section, the match with the time scale is less certain below this depth. For core recovered beneath 100 $\mathrm{m}$ below seafloor, it was mostly impossible to define clear polarity zones, except for a section of reversed polarity in Maastrichtian sediments, from 113.1 to $116.4 \mathrm{~m}$ below seafloor, that is tentatively correlated with Chron $31 \mathrm{r}$. The magnetic stratigraphy shows that sediment accumulation was slow (about $2.5 \mathrm{~m} / \mathrm{m}$.y.) during the late Miocene, but increased to 15.0 to $18.5 \mathrm{~m} / \mathrm{m}$.y. during the late Pliocene and Pleistocene. Missing sections within the Matuyama Chron and an extended Brunhes Chron suggest that actual sediment accumulation rates were at times higher and lower than these averages. Furthermore, differences in sediment accumulation between Site 810 and nearby Site 577 suggest that the normal pelagic sedimentation regime atop Shatsky Rise is perturbed by bottom currents resulting in locally patchy sediment accumulation.
\end{abstract}

\section{INTRODUCTION}

Shatsky Rise is a prominent bathymetric uplift in the western Pacific Ocean, located about $1800 \mathrm{~km}$ east of the Japanese Islands. At its southwest end, it formed at about the same time as the lithosphere, and probably resulted from the initiation of a hot spot (Nakanishi et al., 1989). The rise is elongated, with dimensions of about 400 $\times 1500 \mathrm{~km}$, and is oriented southwest to northeast. Although about half of the edifice is low, rising less than $1 \mathrm{~km}$ from the regional abyssal depth of $5500 \mathrm{~m}$, there are three domal uplifts that rise above $3500 \mathrm{~m}$. The largest and shallowest makes up the southwestern end of the rise and is centered at about $32.5^{\circ} \mathrm{N}, 158.0^{\circ} \mathrm{E}$.

Seven sites on the southwest end of Shatsky Rise were drilled during the Deep Sea Drilling Project (Sites 47, 48, 49, 50, 305, 306, and 577). The oldest sediments recovered by drilling were late Jurassic in age, at Site 306 (Shipboard Scientific Party, 1975), and seismicreflection data indicate that more than $1 \mathrm{~km}$ of sediments cap its summit (Sliter and Brown, this volume). Much of this sedimentary cap is Cretaceous in age (Sliter and Brown, this volume) and was deposited when the rise was located near the equator. Nevertheless, Shatsky's summit has remained above the carbonate compensation depth (CCD) since its formation, so it is has received carbonate sediments throughout its history. Because of this, the rise's sedimentary sections contain a record of climate variations for over 150 m.y., making Shatsky Rise an attractive drilling target for paleoceanographic and paleoclimate studies (Koisumi, 1985; Heath et al., 1985; Leinen, 1985; Janecek, 1985; Bloemendal et al., 1992).

Site 810 was drilled atop Shatsky Rise during Ocean Drilling Program (ODP) Leg 132. Its purpose was a test of the diamond-coring system, which it was hoped would enhance recovery in the alternating soft-hard, ooze-chert layers that characterize the Cretaceous sedimen-

\footnotetext{
${ }^{1}$ Natland, J.H., Storms, M.A., et al., 1993. Proc. ODP, Sci. Results, 132: College Station, TX (Ocean Drilling Program).

${ }^{2}$ Department of Oceanography, Texas A\&M University, College Station, TX 77843 3146, U.S.A.

${ }^{3}$ Ocean Drilling Program, 1000 Discovery Drive, Texas A\&M University, College Station. TX 77845-9547, U.S.A.
}

tary section. Four holes were drilled at Site 810 , but only one (810C) had significant penetration and recovery (Storms, Natland, et al., 1991). Hole $810 \mathrm{C}$ penetrated $136.1 \mathrm{~m}$ below seafloor (mbsf) and was drilled primarily with the advanced hydraulic piston corer (APC) to obtain relatively undisturbed, high-recovery cores from the Cenozoic oozes that rest atop the target Cretaceous section. Fifteen APC cores $(132-810 \mathrm{C}-1 \mathrm{H}$ through $-15 \mathrm{H})$ were recovered along with one extended core barrel core $(132-810 \mathrm{C}-16 \mathrm{X})$. The total recovery was $105.7 \%$ and the sediments consisted mostly of nannofossil ooze (Storms, Natland, et al., 1991).

Biostratigraphic data show that the recovered sediments from Hole $810 \mathrm{C}$ range in age from Maastrichtian to Pleistocene (Storms, Natland, et al., 1991; Premoli Silva et al., this volume). What is more, sedimentological and magnetic susceptibility data (Storms, Natland, et al., 1991) indicate that there is a significant Pliocene-Pleistocene section that appears to record the effects of glacial/interglacial climate cycles. As a consequence, climate-proxy studies of Hole $810 \mathrm{C}$ cores were undertaken by several groups of investigators. Such studies require age control and one of the most precise methods of obtaining age data is magnetic stratigraphy. This report details studies of the paleomagnetism and magnetic stratigraphy of the Hole $810 \mathrm{C}$ cores. We found a relatively clean, well-constrained record of magnetic stratigraphy ranging from late Pleistocene back to late Miocene. We also discovered that a mistake in wiring the cryogenic magnetometer caused shipboard paleomagnetic measurements to give the opposite sign in inclination and added $180^{\circ}$ to declination. This caused incorrect interpretations of the magnetic stratigraphy in the Initial Reports volume (Storms, Natland, et al., 1991).

\section{Magnetic Stratigraphy Assumptions}

Magnetic stratigraphy is based on the concept that the geomagnetic field is approximately dipolar and has two opposite, quasi-stable polarity states in which it spends most of the time. It is assumed that reversals of polarity are virtually synchronous at any locality on Earth and that the durations of constant polarity periods are quasi-random, so that characteristic reversal patterns can be recognized. Furthermore, it is also assumed that sediments record the direction of the 
A $132-810 \mathrm{C}-2 \mathrm{H}-5,125-127 \mathrm{~cm}$ A 9.65 mbst - Chron in (0-100 mT)

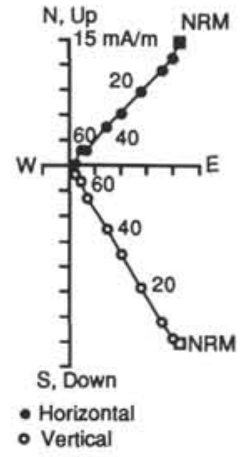

$32-810 \mathrm{C}-4 \mathrm{H}-1,52-54 \mathrm{~cm}$

21.92 mbst - Chron 1r.2r (0-100 mT)

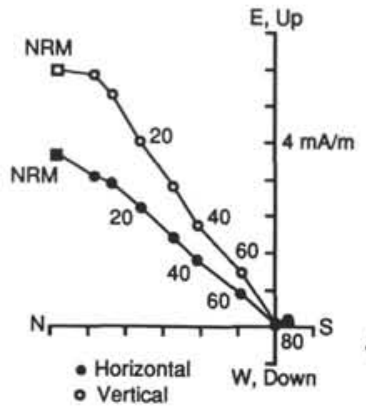

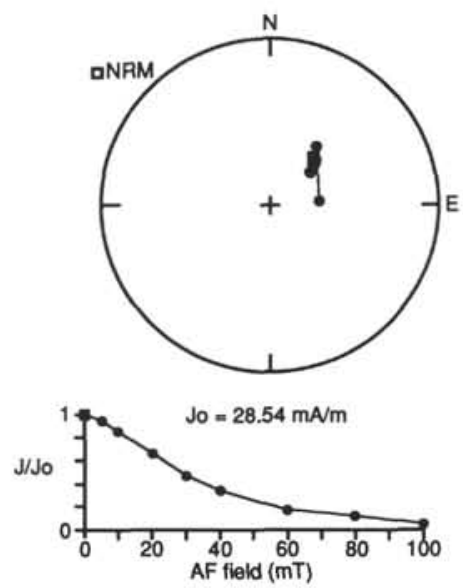
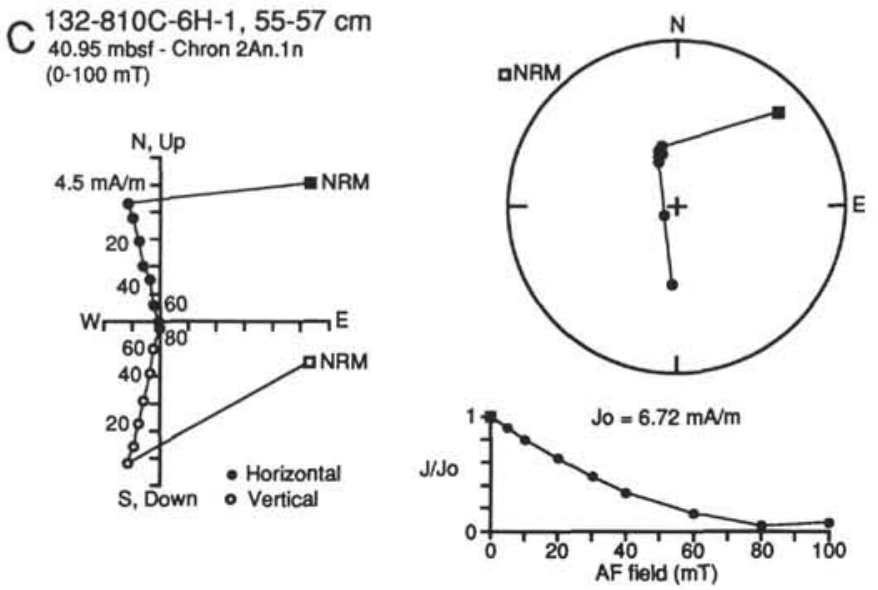

$132-810 \mathrm{C}-8 \mathrm{H}-3,50-52 \mathrm{~cm}$ $62.90 \mathrm{mbst}$ - Chron $3 \mathrm{n} .1 \mathrm{n}$ $(0-100 \mathrm{mT})$
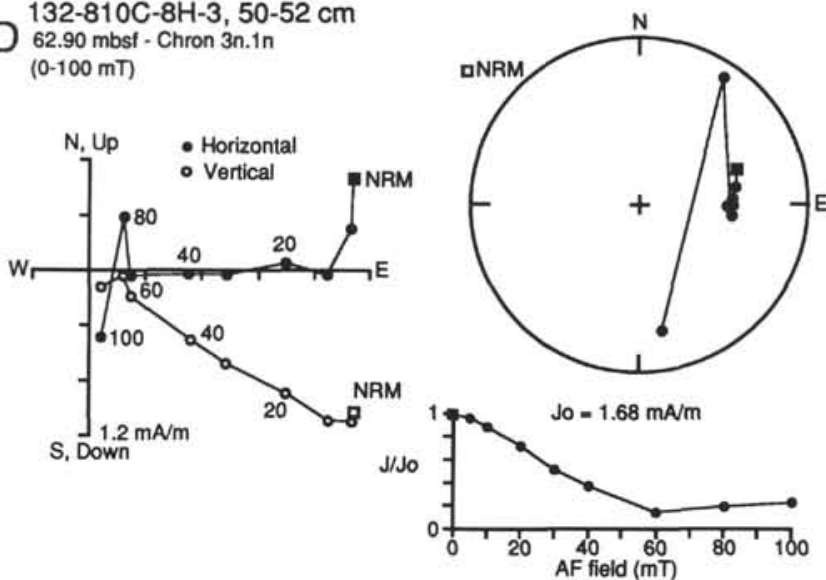

Figure 1.A-F. Behavior of Hole $810 \mathrm{C}$ sediment samples during AF demagnetization. For each sample, three plots are shown: (left) orthogonal vector-endpoint plots, showing projection of the magnetization vector on a horizontal and vertical plane; (upper right) magnetization directions projected on an equal-area net (open symbols denote upper hemisphere; filled symbols denote lower hemisphere); and (lower right) magnetization remaining at a given level of AF demagnetization, normalized to the NRM value (Jo). In all plots the square denotes the NRM direction or magnetization and AF demagnetization steps are the same. Samples in (A) and (B) display little overprint, clear univectorial decay, and MDF values between 25 and $30 \mathrm{mT}$. Samples in (C) and (D) have slightly larger overprints, but these are removed by $10-\mathrm{mT}$ AF demagnetization. These samples also give univectorial decay and have MDF values close to $30 \mathrm{mT}$; however, at high $\mathrm{AF}$ demagnetization steps $(>60 \mathrm{mT})$ they give spurious directions. Samples in $(\mathrm{E})$ and $(\mathrm{F})$ have lower MDF values, 10-15 mT, and give unreliable directions above $40 \mathrm{mT}$. Nevertheless, they display more-or-less univectorial decay for several intermediate demagnetization steps between 10 and $30 \mathrm{mT}$.

geomagnetic field at the time they are deposited, or within a short time thereafter, by the alignment of minute magnetic mineral grains contained within the rain of detritus from the water column or from the biologic formation of magnetic grains near the surface of the sediments. These principles have been verified in both land samples and deep-sea cores by a multitude of studies (e.g., Jacobs, 1984).

A normal polarity magnetic field direction is one that is similar to that at present; for the southern Shatsky Rise this should be a magnetic inclination of $52^{\circ}$ and a declination of nearly $0^{\circ}$. Reversed polarity at the Shatsky Rise should be indicated by a magnetic inclination of $-52^{\circ}$ and declination of about $180^{\circ}$. Cores from Hole $810 \mathrm{C}$ were not azimuthally oriented, so it is impossible to determine absolute declination values; however, the continuity of the APC cores usually allows reversals to be recognized by a $180^{\circ}$ shift in declination values within a given core. Because the Pacific plate has drifted northward about $20^{\circ}$ since Maastrichtian time (Sager and Pringle, 1988), inclinations of older sediments should be less; for example, Maastrichtian sediments should give inclinations averaging $\pm 24^{\circ}$. Most of our study concerns sediments of late Miocene age or younger and the latitudinal motion of the Pacific plate during that time has been small (Duncan and Clague, 1985), so the change in both paleoinclination and paleodeclination for these sediments has also been small.

\section{Magnetic Polarity Time Scales}

The geomagnetic polarity sequence and its correlation to biostratigraphy has been the subject of much study in the past three decades, and as a result there are several time scales that could be used for this study. In recent years, the results from these time scales have tended to converge, so that competing scales are now not very different. In particular, the sequence of reversals has become stable, with most changes being small shifts in the timing of reversals as new calibration data are obtained and with the addition of previously unrecognized short events (e.g., Cande and Kent, 1992).

To make our study comparable with other studies in this volume and elsewhere, we chose a widely cited time scale that was developed especially to tie the magnetic reversal sequence to common microfossil zonations for the Cenozoic (Berggren et al., 1985). More recent time scale studies have found small problems with this time scale. In particular, the Pliocene-Pleistocene reversal sequence has been cali- 
E $132-810 \mathrm{C}-10 \mathrm{H}-6,45-47 \mathrm{~cm}$

86.35 mbst - Chron $4 \mathrm{n} .2 \mathrm{n}$

$(0-40 \mathrm{mT})$

- Horizontal

- Vertical
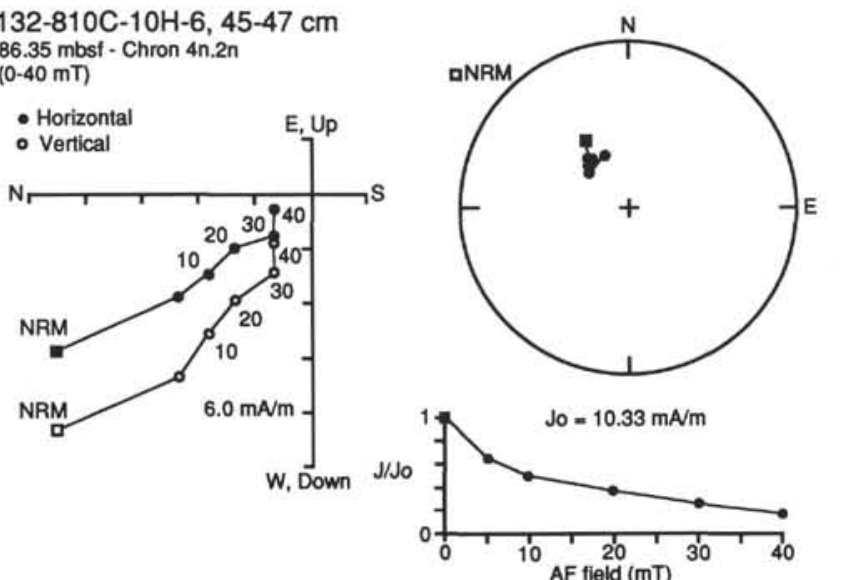

$132-810 \mathrm{C}-12 \mathrm{H}-4,26-28 \mathrm{~cm}$

F 102.16 mbst-middle Miocene $(0-40 \mathrm{mT})$
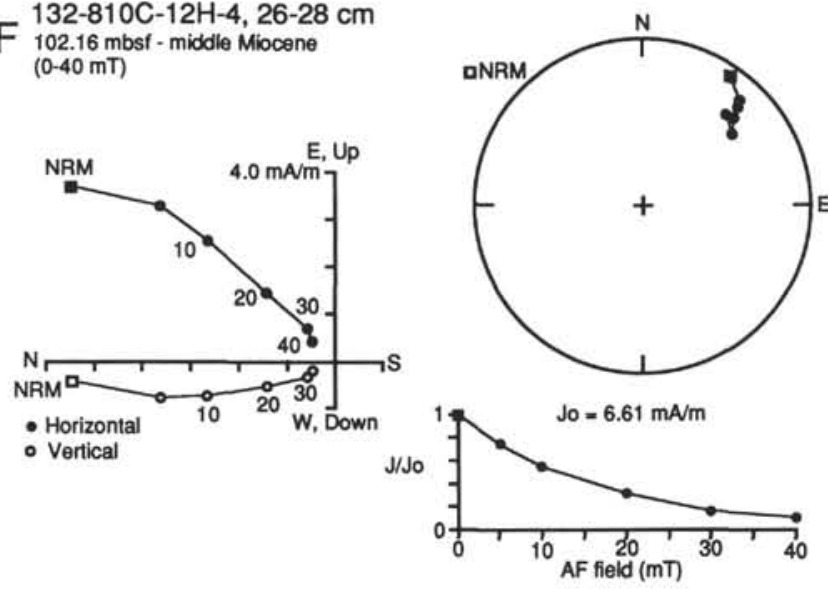

Figure 1 (continued).

brated with orbitally induced climate signals (Shackleton et al., 1990; Hilgen, 1991a, 1991b) and dated with high-resolution radiometric techniques (Tauxe et al., 1992). Because these changes are small (about $8 \%$ or less) and our primary concern here is recognizing the pattern of magnetic reversals, our choice of time scales does not significantly affect our results.

\section{METHODS}

Most measurements were made aboard ship during Leg 132 using the $2 \mathrm{G}$ pass-through cryogenic magnetometer. Archive halves of Cores $132-810 \mathrm{C}-1 \mathrm{H}$ through $-16 \mathrm{X}$ were all measured at a $10-\mathrm{cm}$ spacing. Each core half was measured to obtain the natural remanent magnetization (NRM) and then demagnetized in alternating fields (AF) at 5 and $10 \mathrm{mT}$ to remove overprint magnetizations and isolate the characteristic remanent magnetization (ChRM). Plots of these data shown here have been corrected for the wiring problem mentioned above.

Discrete samples, 5 or $7 \mathrm{~cm}^{3}$ in volume, were taken from the "working halves" of the cores for additional study. Such samples were typically taken at a spacing of one per section (about $1.5 \mathrm{~m}$ ), but in two intervals of Cores $132-810 \mathrm{C}-2 \mathrm{H}$ and $-3 \mathrm{H}$, chosen for detailed magnetic properties studies (Polgreen et al., this volume), the spacing was 10 $\mathrm{cm}$. Shore-based paleomagnetic measurements were made with a CTF discrete-sample cryogenic magnetometer. A subset of these samples (about one in 10) were subjected to stepwise AF demagnetization in fields up to $100 \mathrm{mT}$, typically with about $8-10$ steps (Fig. 1). The results of these pilot samples indicated that the measurements at higher demagnetizations were often unreliable, so the remainder of the samples were typically stepwise demagnetized at 4-5 steps in fields up to $40 \mathrm{mT}$. A series of magnetic properties tests was performed on a subset of the discrete samples to elucidate the type and characteristics of the magnetic grains in the sediments. These tests are described elsewhere in this volume (Polgreen et al., this volume).

Magnetization directions for discrete samples were calculated by averaging several (typically 4-5) directions along sections of univectorial decay using the method of Fisher (1953). Other techniques, such as principal component analysis (Kirschvink, 1980), may be slightly more precise in defining ChRM directions, but for stable samples, such as most of those measured in this study, any difference in directions between these two methods should be negligible.

Discrete sample ChRM inclinations and declinations were plotted versus depth along with shipboard measurements from the passthrough cryogenic magnetometer. This allowed comparison between the more reliable discrete sample results and the more abundant whole core results, respectively. Magnetic reversals were recognized on the basis of simultaneous shifts from positive to negative paleoinclination (or vice versa) and a nearly $180^{\circ}$ change in paleodeclination. Where there were changes in declination without a corresponding change in inclination (or vice versa), either no reversal was interpreted or a questionable reversal was indicated.

For calculating sedimentation rates and comparing age vs. depth curves, we used the Berggren et al. (1985) magnetic polarity reversal time scale. Nevertheless, we also compared our results to the Cande and Kent (1992) time scale, which reflects recent changes in age calibration, but the differences were minor. To identify polarity chrons and subchrons in the table and figures, we used the numbering scheme of Cande and Kent (1992) because it is logical, clear, and allows unambiguous identification of chrons and subchrons. In this system, the major chrons are numbered by their traditional sequence in marine magnetic anomaly profiles. Because the positive anomalies in Cenozoic-Late Cretaceous profiles were given numbers, most chrons begin with a predominantly reversed-polarity period (designated by " $r$ ") and are followed by a predominantly normal-polarity period (designated by " $n$ "). For example, the Gauss Chron is Chron 2A. It begins with Chron $2 \mathrm{Ar}$ and ends with Chron 2An. Within Chron 2An are two reversed polarity subchrons, the Kaena and Mammoth Events, which are numbered $2 \mathrm{An} .1 \mathrm{r}$ and $2 \mathrm{An} .2 \mathrm{r}$, respectively. In the figures and table, we have also identified late Pliocene and Pleistocene chrons and subchrons by their historical names, such as "Brunhes," "Jaramillo," and so forth.

\section{RESULTS}

\section{Magnetic Properties}

NRM values from Hole $810 \mathrm{C}$ sediments ranged from $1.5 \times 10^{-4}$ to $1.8 \mathrm{~A} / \mathrm{m}$ but were usually between $1 \times 10^{-3}$ to $1 \times 10^{-2} \mathrm{~A} / \mathrm{m}$. Such weak magnetizations are typical of mid-gyre, deep-sea carbonate platform sediments, but were nonetheless easily measured with the two cryogenic magnetometers. Isothermal remanent magnetization (IRM) acquisition curves of most samples displayed saturation in low applied magnetic fields $(<0.3 \mathrm{~T})$, suggesting that titanomagnetite grains are the primary magnetic remanence carrier (see Polgreen et al., this volume). Orthogonal-vector plots usually show that these sediments have small overprints and give apparently reliable results after AF demagnetization. For most samples, AF demagnetization above 5-10 $\mathrm{mT}$ produces univectorial decay toward the origin, indicating that overprints have been removed and the ChRM isolated (Fig. 1). This is fortunate because it means that the pass-through measurements taken after 10-mT demagnetization are relatively free of overprint. A characteristic of some of these sediments is that at AF steps higher than about $50-60 \mathrm{mT}$ (but occasionally less) spurious magnetization directions are measured (Fig. 1). This suggests that the samples 


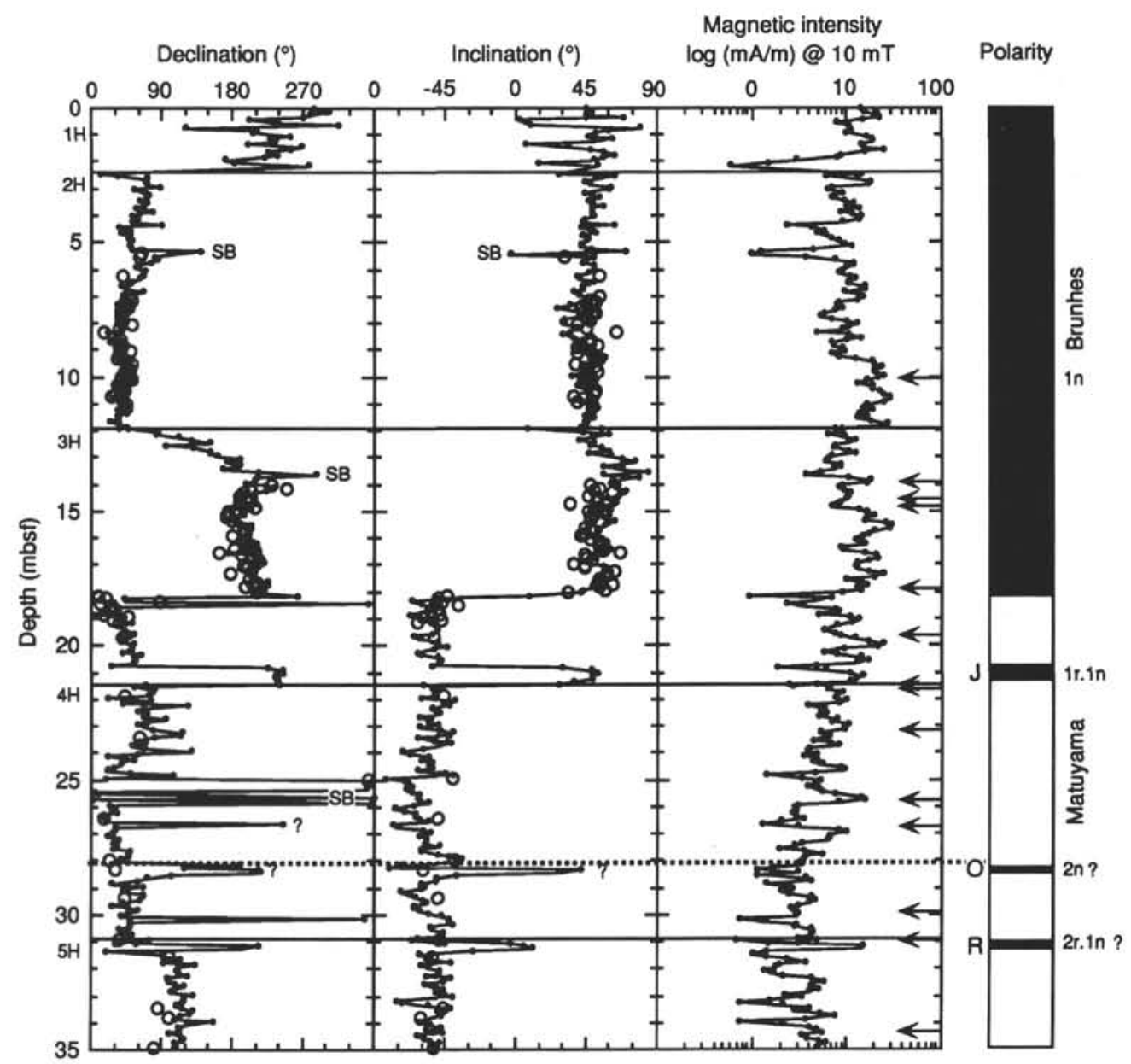

Figure 2. Hole $810 \mathrm{C}$ magnetic data and polarity interpretation. For clarity, the figure is enlarged and divided into three sections that cover $35 \mathrm{~m}$ and one that shows $25 \mathrm{~m}$. Small symbols connected by a line in each column show measurements taken at $10-\mathrm{cm}$ intervals with a pass-through cryogenic magnetometer on archive core halves after AF demagnetization at $10 \mathrm{mT}$. Large, open circles denote measurements made on discrete samples after more complete AF demagnetization. Thin horizontal lines represent boundaries between cores and are labeled on the left, next to the depth scale. Dashed horizontal lines denote hiatuses recognized from the biostratigraphy (Premoli Silva et al., this volume). "SB" denotes anomalous measurements owing to disturbance of the sediments at section breaks, where the core was cut. Arrows show the depth of ash layers (Natland, this volume). In the polarity interpretation column, black indicates normal polarity; white is reversed. Polarity blocks that do not extend across the entire column show uncertain reversals. Hachures indicate indeterminate polarity. Polarity chrons and subchrons are labeled along the edge of the polarity blocks and follow the numbering system devised by Cande and Kent (1992). Named Pliocene-Pleistocene polarity intervals are noted either with the name or a single letter abbreviation. $\mathrm{J}=\mathrm{Jaramillo}, \mathrm{O}=$ Olduvai, $\mathrm{R}=\mathrm{R}$ union, $\mathrm{K}=$ Kaena, $\mathrm{M}=$ Mammoth, $\mathrm{C}=$ Cochiti, $\mathrm{N}=$ Nunivak, $\mathrm{S}=$ Sidufjall, and $\mathrm{T}=$ Thvera .

are susceptible to acquiring an anhysteretic remanent magnetization $(\mathrm{ARM})$ at high $\mathrm{AF}$ demagnetization steps. This problem does not seriously affect most of the samples in this study because a clear ChRM at intermediate demagnetization steps was usually found. However, some samples in the deeper cores (e.g., Fig. 1F) do not show clear univectorial decay, perhaps because the ChRM cannot be completely separated from the overprint. This may be the source of some of the difficulties in delineating magnetic polarities toward the bottom of the hole. Most samples gave mean destructive field (MDF) values of $30-40 \mathrm{mT}$ (see Polgreen et al., this volume), suggesting that when it was possible to isolate a ChRM, that magnetization is durable and has geologic significance.

Because of the multitude of closely-spaced measurements made with the pass-through cryogenic magnetometer, magnetic reversals were easily defined in the upper 100 mbsf (Fig. 2). With the exception of a few places where core or section breaks or ash layers perturb the measurements, the inclination and declination record delineates a clear reversal record. Discrete and pass-through inclination and declination values usually agree well, particularly in the upper $90.5 \mathrm{~m}$ of the section. Paleoinclinations are usually about $\pm 50^{\circ}$, in good agreement with the expected geocentric axial dipole inclination of $52^{\circ}$.

At 90.5 and 100.0 mbsf, the biostratigraphy data show hiatuses, the upper one between sediments of nannofossil Zones CN6 and CN8 of middle and late Miocene age, respectively, and the lower one separating middle Miocene Zone CN5 and Eocene Zone CP11 sediments (Premoli Silva et al., this volume). Below each hiatus, the agreement between the 10-mT demagnetized pass-through and discrete sample measurements is progressively worse (Fig. 2). In this section, the paleoinclinations are generally much smaller than the 10 -mT pass-through values. This is consistent with these sediments acquiring a nearly vertical drilling-induced overprint. On the other hand, many discrete samples in the lower sections of the hole showed 


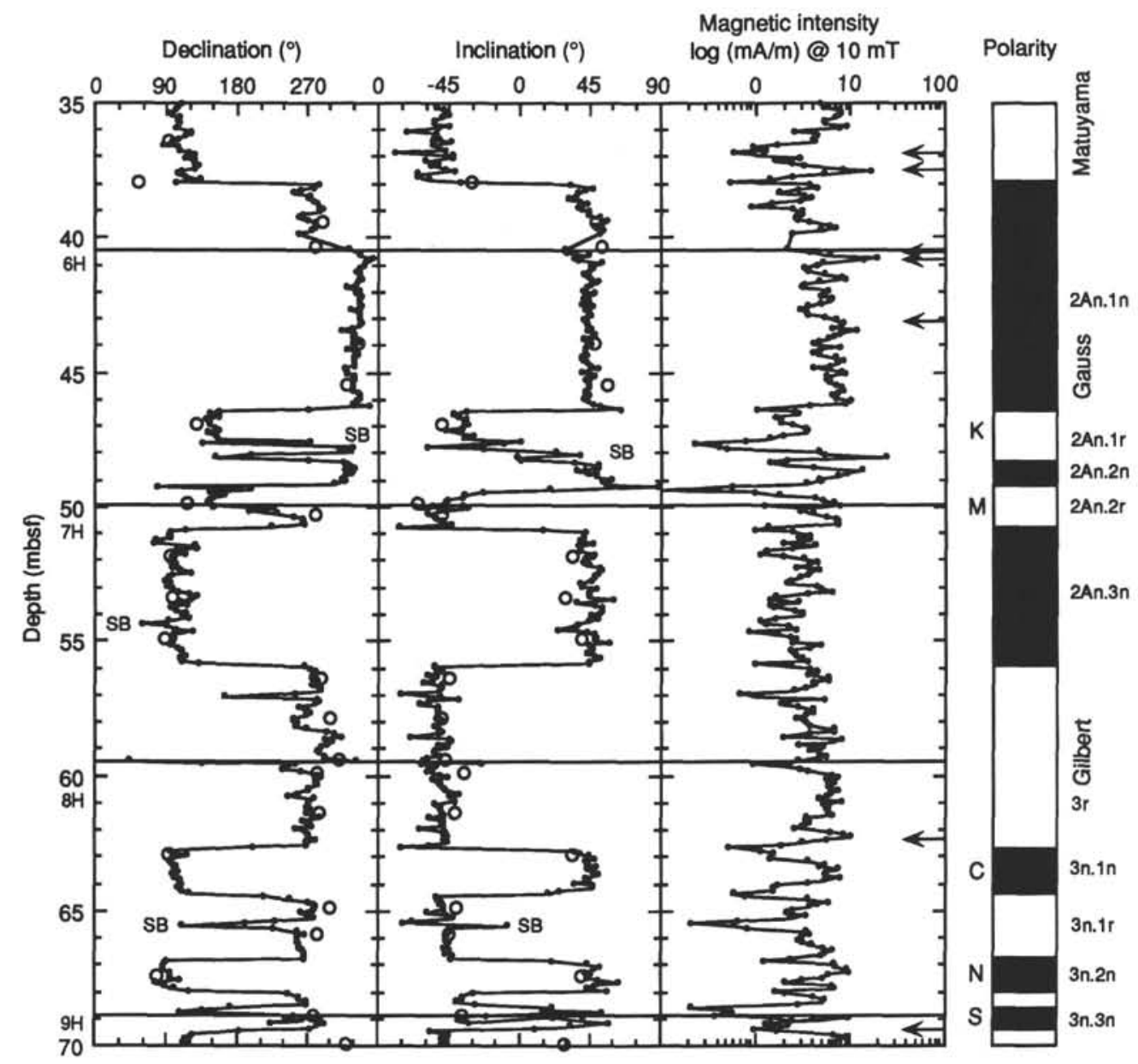

Figure 2 (continued).

a behavior similar to that of Sample 132-810C-12H-4, 26-28 cm (Fig. $1 \mathrm{~F})$, which had a low-inclination NRM value and a low MDF value $(<15 \mathrm{mT})$, and did not give as well-defined a univectorial decay sequence during $\mathrm{AF}$ demagnetization as samples from higher up. Because of this more unreliable behavior, it was not possible to decipher a clear reversal pattern below about $108 \mathrm{mbsf}$, and the pattern between 100 to $108 \mathrm{mbsf}$ is somewhat questionable (Fig. 2).

\section{Reversal Sequence}

Below the seafloor, paleoinclinations are positive to a depth of 18.1 mbsf, indicating normal polarity (Table 1 and Fig. 2). Just below this, at $20.8 \mathrm{mbsf}$ to the bottom of Core $132-810 \mathrm{C}-3 \mathrm{H}$ at $21.4 \mathrm{mbsf}$, is a short normal-polarity section. This is the expected pattern for the Brunhes normal chron (Chron 1n) and Jaramillo Subchron (Chron $1 \mathrm{r} .1 \mathrm{n})$. However, there are two discrepancies with the spacing of these normal-polarity sections. The spacing between the upper boundary of the Jaramillo and the lower boundary of the Brunhes indicates a sedimentation rate of $15.0 \mathrm{~m} / \mathrm{m}$.y. (Fig. 3). At this rate, the Brunhes should only be $11.0 \mathrm{~m}$ in length, but the Jaramillo should cover $1.1 \mathrm{~m}$. This observation suggests that about half of the Jaramillo is missing, whereas the Brunhes section is $65 \%$ too long. Both discrepancies could have resulted from changing sedimentation rates; although, the Jaramillo Chron extends to the bottom of Core $132-810 \mathrm{C}-3 \mathrm{H}$, so it is also possible that the missing part was not cored owing to a gap between cores. Uneven sedimentation is consistent with the observation that the ash layers do not correlate well between Sites 810 and
577 , the latter located only $11.7 \mathrm{~km}$ to the west of Site 810 and about $50 \mathrm{~m}$ deeper (Natland, this volume).

Farther downsection, between 38.0 and $55.8 \mathrm{mbsf}$, is another long, normal-polarity interval interrupted by two short reversed-polarity intervals. This is the classic signature of the Gauss Chron (Chron 2An) with the Kaena and Mammoth reversed-polarity subchrons (Chrons 2An.1r and 2An.2r). Between the bottom of the Brunhes and the top of the Gauss sections is a 19.9-m-long section dominated by reversed polarity. This is the Matuyama Chron (Chron 1r).

The Matuyama should contain the prominent, 0.22 -m.y.-duration Olduvai Chron (Chron 2n); however, it is not evident in the plot of inclinations and declinations. There are two short normal polarity sections, 28.3 to $28.6 \mathrm{mbsf}$ and 31.0 to $31.4 \mathrm{mbsf}$, both of which show reversals of both inclination and declination. Interpreting the upper one as the bottom of the Olduvai Chron and the lower as the Réunion Subchron gives a sedimentation rate approximately the same as that implied by the Gauss Chron reversals below (Fig. 3). Additionally, a hiatus occurs at about $28 \mathrm{mbsf}$, including part of the upper Pliocene and lower Pleistocene (Premoli Silva et al., this volume), consistent with our interpretation of a truncated Olduvai Chron. Alternatively, both short polarity zones could be spurious and caused by disturbance of the sediments. The upper zone occurs just below a hiatus and the lower zone is at the top of a core (Fig. 2); however, the fact that our interpretation gives a nearly constant sedimentation rate through this section gives it credence.

Between the base of the Gauss Chron, at $55.8 \mathrm{mbsf}$, and the hiatus between upper and middle Miocene sediments at about $90.5 \mathrm{mbsf}$ 

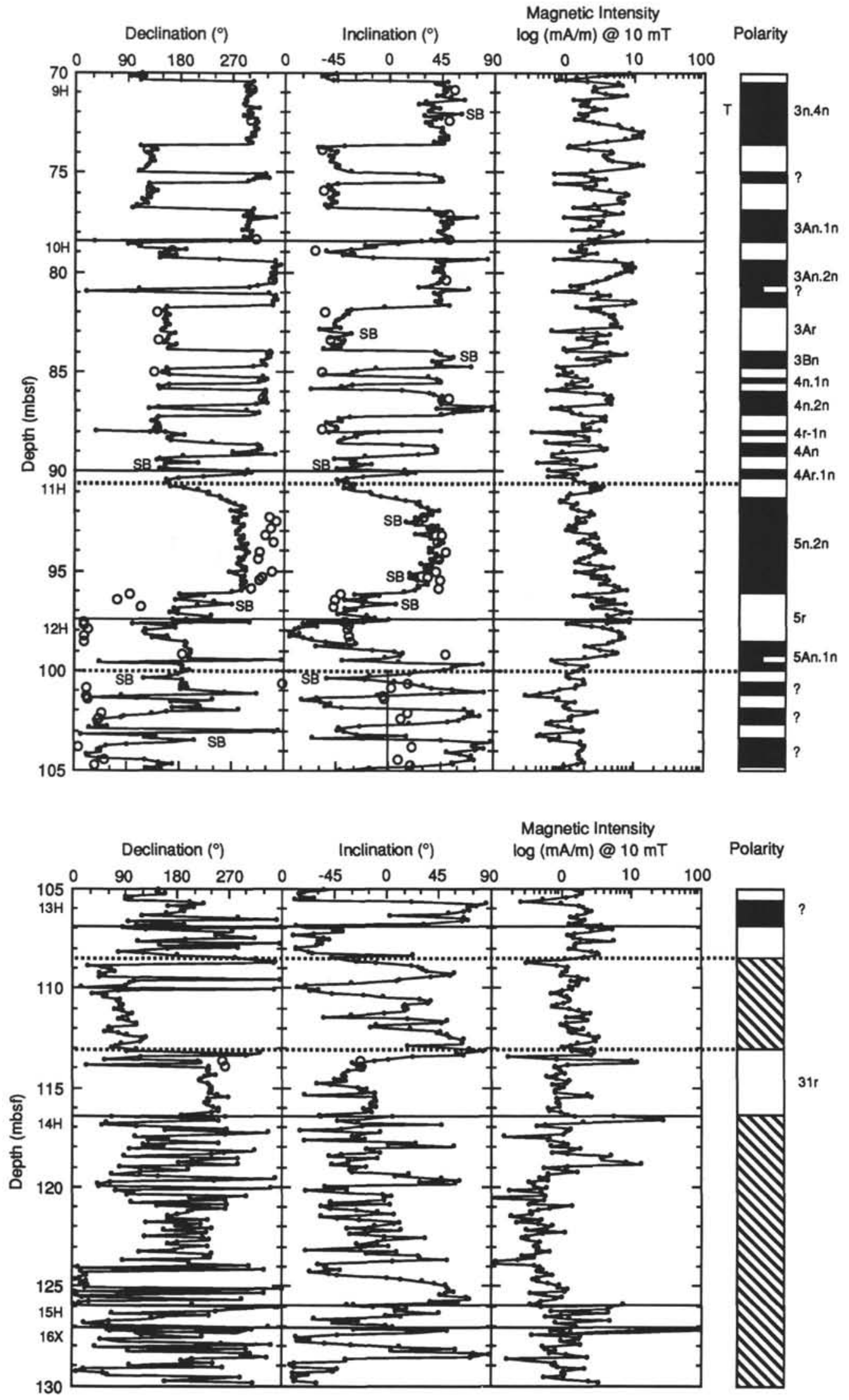

Figure 2 (continued). 
Table 1. Ages and depths of magnetostratigraphic boundaries, Hole $810 \mathrm{C}$.

\begin{tabular}{|c|c|c|c|}
\hline $\begin{array}{l}\text { Depth } \\
\text { (mbsf) }\end{array}$ & $\begin{array}{l}\text { Age }^{a} \\
\text { (Ma) }\end{array}$ & $\begin{array}{l}\mathrm{Age}^{\mathrm{b}} \\
\text { (Ma) }\end{array}$ & Chron $^{c}$ \\
\hline 18.1 & 0.73 & 0.78 & In(o), Brunhes/Matuyama \\
\hline 20.8 & 0.91 & 0.98 & 1r. In(o), top Jaramillo \\
\hline 28.6 & 1.88 & 1.98 & $2 \mathrm{n}(\mathrm{o})$, bottom Olduvai \\
\hline 31.3 & 2.14 & 2.21 & 2r.1n, middle Réunion \\
\hline 38.0 & 2.47 & 2.60 & 2An. $\ln (\mathrm{y})$, Matuyama/Gauss \\
\hline 46.3 & 2.92 & 3.05 & 2An.2n(y), top Kaena \\
\hline 49.2 & 3.08 & 3.13 & 2An.3n(y), top Mammoth \\
\hline 50.8 & 3.18 & 3.22 & $2 \mathrm{An} .3 \mathrm{n}(\mathrm{y})$ \\
\hline 55.8 & 3.40 & 3.55 & 2An.3n(o), Gauss/Gilbert \\
\hline 62.7 & 3.88 & 4.03 & 3n. In(y), top Cochiti \\
\hline 64.3 & 3.97 & 4.13 & 3n. $\ln (0)$, bottom Cochiti \\
\hline 66.7 & 4.10 & 4.27 & 3n.2n(y), top Nunivak \\
\hline 67.9 & 4.24 & 4.43 & 3n.2n(o), bottom Nunivak \\
\hline 68.5 & 4.40 & 4.61 & 3n.3n(y), top Sidufjall \\
\hline 69.3 & 4.47 & 4.69 & 3n. $3 \mathrm{n}(\mathrm{o})$, bottom Sidufjall \\
\hline 70.4 & 4.57 & 4.81 & 3n. $4 n(y)$, top Thvera \\
\hline 73.6 & 4.77 & 5.05 & 3n.4n(o), bottom Thvera \\
\hline 76.8 & 5.35 & 5.71 & 3An. $\ln (y)$ \\
\hline 79.2 & 5.68 & 6.08 & $3 \mathrm{An} \cdot 2 \mathrm{n}(\mathrm{y})$ \\
\hline 81.7 & 5.89 & 6.38 & $3 \mathrm{An} \cdot 2 \mathrm{n}(\mathrm{o})$ \\
\hline 83.9 & 6.37 & 6.74 & $3 \mathrm{Bn}(\mathrm{y})$ \\
\hline 84.8 & 6.50 & 6.90 & $3 \mathrm{Bn} . \ln (\mathrm{o})$ \\
\hline 85.2 & 6.70 & 7.25 & $4 \mathrm{n} \cdot \ln (\mathrm{y})$ \\
\hline 85.5 & 6.78 & 7.38 & $4 n . \ln (0)$ \\
\hline 86.0 & 6.85 & 7.46 & $4 n \cdot 2 n(y)$ \\
\hline 87.2 & 7.28 & 7.89 & $4 n \cdot 2 n(0)$ \\
\hline 88.0 & 7.35 & 8.05 & $4 r \cdot \ln (y)$ \\
\hline 88.2 & 7.41 & 8.08 & $4 r . \ln (0)$ \\
\hline 88.6 & 7.90 & 8.53 & $4 A n(y)$ \\
\hline 89.2 & 8.21 & 8.86 & $4 \mathrm{An}(\mathrm{o})$ \\
\hline 89.9 & 8.41 & 9.07 & $4 \mathrm{Ar} \cdot \ln (\mathrm{y})$ \\
\hline 91.0 & 8.92 & 9.78 & $5 \mathrm{n} \cdot 2 \mathrm{n}(\mathrm{y})$ \\
\hline 96.1 & 10.42 & 10.83 & $5 n \cdot 2 n(o)$ \\
\hline 98.5 & 11.03 & 11.38 & $5 \mathrm{r} \cdot 2 \mathrm{n}(\mathrm{y})$ \\
\hline
\end{tabular}

${ }^{\mathrm{a}}$ From Berggren et al. (1985) time scale.

bFrom Cande and Kent (1992) time scale.

'Designations follow Cande and Kent (1992) time scale; $(0)=$ old boundary, $(y)=$ young boundary.

(Premoli Silva et al., this volume), there is a series of 13 normalpolarity zones (Fig. 2). Unfortunately, this part of the early Pliocene to late Miocene polarity-reversal sequence contains many chrons and the pattern is not as distinctive as later chrons. The first four normalpolarity intervals below the base of the Gauss have been interpreted as the Cochiti, Nunivak, Sidufjall, and Thvera Subchrons ( $3 n .1 n$, $3 n .2 n, 3 n .3 n$, and $3 n .4 n$, respectively) of the Gilbert Chron. The relative lengths of these subchrons appear approximately correct, with the Thvera the longest, the Sidufjall the shortest, and the Nunivak and Cochiti of intermediate and similar length. This interpretation is consistent with the biostratigraphy, which has early Pliocene nannofossil Zones CN10a through CN11 and foraminifer Zones N18 to N19 correlated with the four normal-polarity Gilbert subchrons (Premoli Silva et al., this volume).

Between the base of the Thvera Subchron, at $73.6 \mathrm{mbsf}$, and the 90.5 mbsf hiatus, identification of the reversal pattern is less certain because there are many reversals, the sedimentation rate slowed (Fig. 3; Premoli Silva et al., this volume), and the reversal pattern does not exactly fit the polarity reversal time scale. To be as consistent as possible with the biostratigraphy, which shows the boundary between nannofossil Zones $\mathrm{CN} 9 \mathrm{~b}$ and $\mathrm{CN} 10 \mathrm{a}$ in the lower part of Core $132-810 \mathrm{C}-9 \mathrm{H}$, we correlated the two relatively longer normal intervals, between 76.8 and 81.7 mbsf, as Chrons 3An. $\mathrm{n}$ and $3 \mathrm{An} .2 \mathrm{n}$. These are the two significant normal-polarity periods between the Gilbert (Chron $3 \mathrm{n}$ ) and Chron $4 \mathrm{n}$ in most time scales. A problem with our interpretation is appearance of a clear normal polarity period between 75.0 and $75.5 \mathrm{mbsf}$ that is not included in the time scale. If we identify this short normal interval as one of the Chron $3 \mathrm{An}$ subchrons, then the pattern of reversals fits neither the time scale nor the biostratigraphy as well.

In the magnetic polarity time scale, Chrons $3 \mathrm{~B}$ and 4 contain numerous subchrons. We interpreted the longest two normal polarity

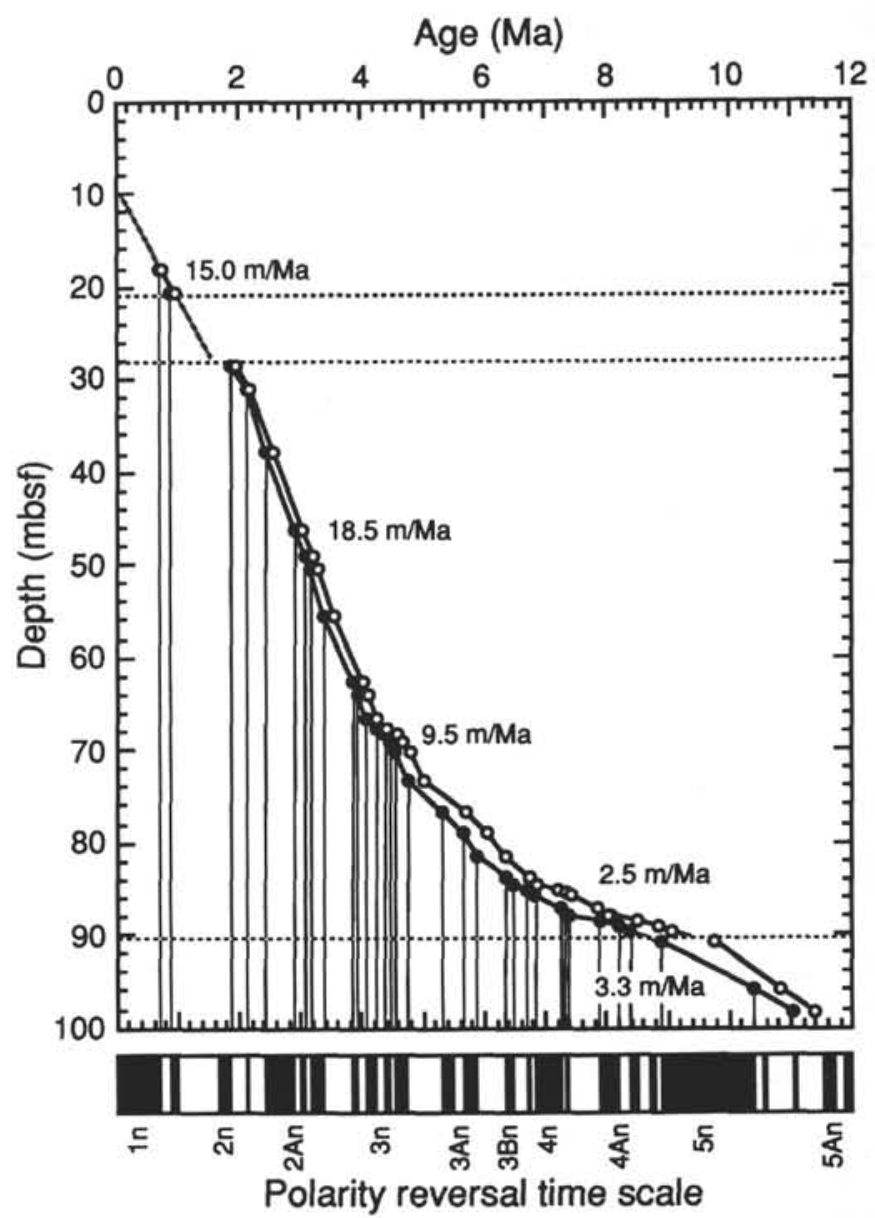

Figure 3. Age vs. depth, Hole $810 \mathrm{C}$, determined from magnetostratigraphy. Circles show ages of identified magnetostratigraphic boundaries (Table 1): filled symbols were plotted with magnetochron boundary dates from the time scale of Berggren et al. (1985), whereas open symbols are from the Cande and Kent (1992) time scale which includes recent adjustments to boundary ages derived from astronomical calibration and high-precision radiometric dating. The average sediment-accumulation rates, given next to sections of the curves, are derived from the Berggren et al. (1985) time scale. Horizontal dashed lines represent hiatuses recognized from the biostratigraphy (Premoli Silva et al., this volume).

zones in the sequence between 84 to 91 mbsf as Subchrons 3Bn and $4 n .2 n$, which are the two longest in the time scale during this time interval. The remaining normal intervals were matched up to other subchrons in the polarity sequence of Chrons $3 \mathrm{~B}$ and 4 , with the result that most subchrons were matched with a normal interval in the sediment column and the model is in reasonably good agreement with biostratigraphy, which has nannofossil Zone CN8 just above the 90.5 mbsf hiatus (Premoli Silva et al., this volume). Nevertheless, the match of sediment polarity interval lengths with the time scale is imperfect, so there may be small errors in the identification of polarity chrons in this section. The less-than-optimal match between the time scale and observed polarity in this interval may be a result of slower and less-continuous sedimentation, as the implied sedimentation rate is only $2.5 \mathrm{~m} / \mathrm{m}$.y., compared with 9.5 to $18.0 \mathrm{~m} / \mathrm{m}$.y. above (Fig. 3).

Between the 90.5 and 100 mbsf hiatuses, the sediments are mainly of normal polarity (Fig. 2) and of middle Miocene age, nannofossil Zones CN5 and CN6 (Premoli Silva et al., this volume). Consequently, we tentatively correlate the long normal interval between 91.0 and $96.1 \mathrm{mbsf}$ as the distinctive, long normal period of Subchron $5 \mathrm{n} .2 \mathrm{n}$ and the reversed interval just below it as Chron $5 \mathrm{r}$ (Fig. 2). This 
normal zone is observed just above the boundary between Zones CN5 and CN6 (Premoli Silva et al., this volume), just as in the Berggren et al. (1985) time scale. Given the approximate sedimentation rate implied by the length of Subchron $5 n .2 n$, the normal interval from 98.5 to 100.0 mbsf should be Subchron 5 r.2n. A problem with this interpretation is that Subchron $5 \mathrm{n} .2 \mathrm{n}$ should be bracketed on the top and bottom by Subchrons, $5 \mathrm{n} .1 \mathrm{n}$ and $5 \mathrm{r}$. $1 \mathrm{n}$, but these short events are not seen in the polarity record. Nevertheless, our interpretation is consistent with the biostratigraphy and gives a smooth sedimentation curve (Fig. 3).

Beneath the 100 mbsf hiatus, we interpreted polarity intervals in some of the section, but were unable to identify most of these intervals. Furthermore, between 108.5 and 113.0 mbsf and 116.4 and 130.0 mbsf we were unable to identify polarity. Between 99.9 and $108.5 \mathrm{mbsf}$ the section is early Eocene in age and contains calcareous nannofossil from Zone CP11 (Premoli Silva et al., this volume). According to the time scale, Zone CP11 is a short interval of virtually constant, reversed polarity (Berggren et al., 1985). However, in the section between 99.9 and $106.9 \mathrm{mbsf}$, there appears to be at least four normal polarity intervals. It is unclear whether the problem is with the time scale or the magnetic stratigraphy, although the magnetic record in the sediments is not nearly as clear as that in the younger sections of Hole $810 \mathrm{C}$.

An upper Paleocene section is between the hiatus at $108.5 \mathrm{mbsf}$ and another hiatus at $113.1 \mathrm{mbsf}$ (Premoli Silva et al., this volume). The magnetic record is too confused in this interval to interpret reversals reliably. The paleoinclinations show several excursions from positive to negative values, suggesting reversals, but the declination remains virtually the same throughout the entire interval. We interpreted the polarity of this interval as indeterminate (Fig. 2).

In the Maastrichtian sediments below 113.1 mbsf, a similar situation exists. Paleoinclinations and paleodeclinations oscillate abruptly with depth. Consequently, from $116.4 \mathrm{mbsf}$ to the bottom of Hole $810 \mathrm{C}$ the polarity is indeterminate. However, between 113.1 and $116.4 \mathrm{mbsf}$, a short interval shows consistently negative paleoinclinations that are corroborated by discrete sample measurements (Fig. 2). The sediments at this depth contain the calcareous nannofossil Quadrum trifidum (Premoli Silva et al., this volume), which lived about the time of Chron 32 in the Maastrichtian (Kent and Gradstein, 1985). Thus, the reversed polarity sediment could have been deposited during Subchrons 32r.2r, $32 \mathrm{r} .1 \mathrm{r}$, and $32 \mathrm{n} .1 \mathrm{r}$, which bracket $32 \mathrm{n} .2 \mathrm{n}$, the main normal period of Chron 32, or in Chron 31r, a 2.0-m.y. period of reversed polarity that followed Chron 32 (Cande and Kent, 1992). We chose Chron 31r because of its length (Fig. 2).

\section{Sedimentation Rates}

The interpreted magnetostratigraphy and biostratigraphy in the upper $80 \mathrm{mbsf}$ of Hole $810 \mathrm{C}$ are in good agreement and suggest that sediment accumulation was uneven and interrupted by lacunas (Figs. 2 and 3). Above a hiatus at $90.5 \mathrm{mbsf}$, separating middle Miocene from upper Miocene sediments, the sedimentation rate was evidently slow, with an average accumulation of only $2.5 \mathrm{~m} / \mathrm{m}$.y. The accumulation rate increased to $9.5 \mathrm{~m} / \mathrm{m}$.y. in early Pliocene time and 18.5 $\mathrm{m} / \mathrm{m}$.y. by the late Pliocene (Fig. 3). A missing section of the Matuyama Chron suggests a hiatus during the early Pleistocene, but the top of the Jaramillo Subchron and the boundary between Brunhes and Matuyama Chrons were observed and imply a sediment-accumulation rate of $15.0 \mathrm{~m} / \mathrm{m}$.y. During the normal-polarity Brunhes Chron, the accumulation rate must have been even higher because the Brunhes section is $65 \%$ longer than expected from the extrapolation of the spacing between the Brunhes/Matuyama boundary and Jaramillo.

It is interesting to compare the age vs. depth curve for Hole $810 \mathrm{C}$ to that derived from the magnetic stratigraphy of Hole 577 (Bleil, 1985 ), located only $11.7 \mathrm{~km}$ to the west and about $50 \mathrm{~m}$ deeper. The most significant difference between the two holes is that most of the Miocene section found at Hole $810 \mathrm{C}$ is missing from Hole 577 (Fig.

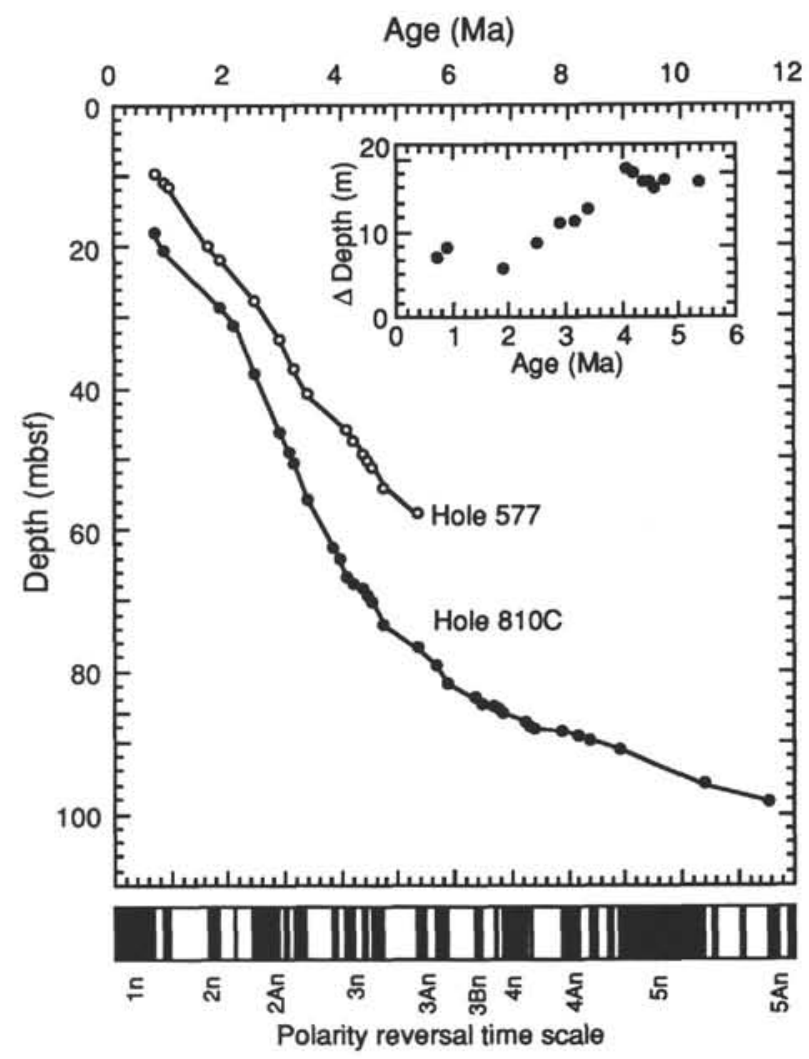

Figure 4. Comparison of age vs, depth, Holes $810 \mathrm{C}$ and 577. Circles denote depth vs. age of magnetostratigraphic boundaries, using ages from the Berggren et al. (1985) time scale. Hole 577 magnetostratigraphy is from Bleil (1985). The inset plot shows differences in sub-seafloor depths of magnetochron boundaries in the two holes (Hole $810 \mathrm{C} \mathrm{mbsf}$ minus Hole $577 \mathrm{mbsf}$ ) and is plotted at the same scale as the larger plot.

4), where Gilbert Chron (uppermost Miocene to lower Pliocene) sediments overlie Eocene sediments. The overall accumulation rate in Hole 577 also appears to have been more consistent, averaging about $11.0 \mathrm{~m} / \mathrm{m} . \mathrm{y}$. through the entire Pliocene-Pleistocene. Because the sediment-accumulation rate was higher at Site 810, the Hole 577 curve plots above the Hole $810 \mathrm{C}$ curve on Figure 4 and the two diverge with depth. Looking at the differences in sub-seafloor depth of the magnetochrons (Fig. 4), it appears that the sedimentation rates were different at the two sites primarily during the Brunhes Chron and the period 2-4 Ma. About $8 \mathrm{~m}$ of sub-seafloor depth difference occurred during the Brunhes Chron, but there were no magnetic reversals to show whether the accumulated difference occurred progressively or suddenly. However, in the period 2-4 Ma, the magnetochron spacing shows that there was a progressive offset in subseafloor depths between the two holes, implying a systematically higher sediment accumulation rate at Site 810.

Although the average sediment-accumulation rate is seemingly more consistent at Site 577 than at Site 810, many more ash layers were noted at the latter (Natland, this volume), implying that sedimentation was less continuous at Site 577. This could indicate that there were many shorter periods of nondeposition at Site 577 . Nevertheless, the large differences in the sediment-accumulation rates and hiatus locations at these two nearby sites indicate that sedimentation has been patchy and localized atop Shatsky Rise. This is also consistent with the observation that magnetic susceptibility curves from the two sites are difficult to correlate, despite their proximity (Polgreen et al., this volume). These observations suggest that currents, either contour currents or turbidity flows, have significantly modified the pelagic sedimentation regime atop Shatsky Rise. Indeed, differences 
in the magnetochron spacing and depth between Holes 577 and $577 \mathrm{~A}$ (Bleil, 1985), located only a few tens of meters apart, suggest that sediment accumulation is variable even on a small scale.

\section{CONCLUSIONS}

Hole $810 \mathrm{C}$ sediments are mostly reliable magnetic field recorders that are not generally susceptible to the acquisition of large overprints. With a minimal treatment of AF demagnetization, usually $10 \mathrm{mT}$ or less, a consistent and apparently reliable magnetization direction is obtained. Because of this, magnetic reversals in the upper 100 mbsf are clear. The sequence shows the Brunhes Chron at the seafloor and a Pliocene-Pleistocene sequence extending through the Matuyama and Gauss Chrons to the Gilbert Chron, which has a base is at 76.8 mbsf. Within this section, the reversal sequence departs from that expected by having an extended Brunhes Chron ( $65 \%$ too long) and missing part of the Jaramillo Subchron and all or most of the Olduvai Subchron. These deviations imply uneven sediment-accumulation rates. In the Miocene section below the Gilbert Chron, the magnetic polarity zones seem clear, but have lengths and spacings that do not precisely fit the polarity reversal time scale: there is at least one short polarity zone that cannot be matched to the time scale, and the slow sediment-accumulation rate compresses the section. These factors make the match between the observed magnetozones and the polarity reversal time scale less certain. Nevertheless, the interpreted reversal sequence above $90.5 \mathrm{mbsf}$ is in good agreement with biostratigraphy. Between hiatuses at 90.5 and $99.9 \mathrm{mbsf}$, there is a long normal zone that was correlated, following biostratigraphy, to the distinctive long normal subchron associated with Chron $5 \mathrm{n}$. Below $100 \mathrm{mbsf}$, the polarity pattern is not clear in sections dated by calcareous nannoplankton to be Eocene to Maastrichtian in age. One short section of reversed polarity, recognized from 113.1 to $116.4 \mathrm{mbsf}$, is tentatively correlated with Chron $31 \mathrm{r}$.

The sediment-accumulation rate at Site 810 was slow in the middle and late Miocene, at only $2.5 \mathrm{~m} / \mathrm{m}$.y. Accumulation increased throughout the Pliocene-Pleistocene and eventually reached average values of 15.0 to $18.5 \mathrm{~m} / \mathrm{m}$.y. in the late Pleistocene. However, the longer-thanexpected Brunhes magnetozone and missing sections of the Matuyama Chron imply that the sediment-accumulation rate has been uneven, particularly during the late Pliocene and Pleistocene, so actual rates may have been episodically higher or lower than the averages. A comparison of the magnetostratigraphic age vs. depth curves between Site 810 and Site 577 , located $11.7 \mathrm{~km}$ apart, show significant differences that indicate large changes in sediment accumulation over this short distance. Taken with evidence of uneven accumulation within these holes, the implication is that the normal rain of pelagic sedimentation was perturbed during the Neogene by bottom currents that have moved the sediments about the summit of Shatsky Rise.

\section{ACKNOWLEDGMENTS}

The authors thank JOL/USSAC for providing the funding to carry out this study. We also acknowledge Jeff Gee and Robert Musgrave for helpful reviews.

\section{REFERENCES ${ }^{*}$}

Berggren, W.A., Kent, D.V., Flynn, J.J., and Van Couvering, J.A., 1985. Cenozoic geochronology. Geol. Soc. Am. Bull., 96:1407-1418.
Bleil, U., 1985. The magnetostratigraphy of northwest Pacific sediments, Deep Sea Drilling Project Leg 86. In Heath, G.R., Burckle, L.H., et al., Init. Repts. DSDP, 86: Washington (U.S. Govt. Printing Office), 441-458.

Bloemendal, J., King, J.W., Hall, F.R., and Doh, S.-J., 1992. Rock magnetism of late Neogene and Pleistocene deep-sea sediments: relationship to sediment source, diagenetic process, and sediment lithology. J. Geophys. Res., 97:4361-4375.

Cande, S.C., and Kent, D.V., 1992. A new geomagnetic polarity timescale for the Late Cretaceous and Cenozoic. J. Geophys. Res., 97:13917-13951.

Duncan, R.A., and Clague, D.A., 1985. Pacific plate motions recorded by linear volcanic chains. In Nairn, A.E.M., Stehli, F.G., and Uyeda, S. (Eds.), The Ocean Basins and Margins (Vol. 7A): The Pacific Ocean: New York (Plenum), 89-121.

Fisher, R.A., 1953. Dispersion on a sphere. Proc. R. Soc. London A, 217:295-305.

Heath, G.R., Rea, D.H., and Levi, S., 1985. Paleomagnetism and accumulation rates of sediments at Sites 576 and 578, Deep Sea Drilling Project Leg 86, western North Pacific. In Heath, G.R., Burckle, L.H., et al., Init. Repts. DSDP, 86: Washington (U.S. Govt. Printing Office), 459-502.

Hilgen, F.J., 1991a. Astronomical calibration of Gauss to Matuyama sapropels in the Mediterranean and implication for the Geomagnetic Polarity Time Scale. Earth Planet. Sci. Lett., 104:226-244.

1991b. Extension of the astronomically calibrated (polarity) time scale to the Miocene/Pliocene boundary. Earth Planet. Sci. Lett., 107:349-368.

Jacobs, J.A., 1984. Reversals of the Earth's Magnetic Field: Bristol (Adam Hilger).

Janecek, T.R., 1985. Eolian sedimentation in the Northwest Pacific Ocean: a preliminary examination of the data from Deep Sea Drilling Project Sites 576 and 578. In Heath, G.R., Burckle, L.H., et al., Init. Repts. DSDP, 86: Washington (U.S. Govt. Printing Office), 589-603.

Kent, D.V., and Gradstein, F.M., 1985. A Cretaceous and Jurassic geochronology. Geol. Soc. Am. Bull., 96:1419-1427.

Kirschvink, J.L., 1980. The least-squares line and plane and analysis of palaeomagnetic data. Geophys. J. R. Astron. Soc., 62:699-718.

Koizumi, I., 1985. Late Neogene paleoceanography in the western north Pacific. In Heath, G.R., Burckle, L.H., et al., Init. Repts. DSDP, 86: Washington (U.S. Govt. Printing Office), 429-438.

Leinen, M., 1985. Quartz content of Northwest Pacific Hole 576A and implications for Cenozoic eolian transport. In Heath, G.R., Burckle, L.H., et al., Init. Repts. DSDP, 86: Washington (U.S. Govt. Printing Office), 581-588.

Nakanishi, M., Tamaki, K., and Kobayashi, K., 1989. Mesozoic magnetic anomaly lineations and seafloor spreading history of the Northwestern Pacific. J. Geophys. Res., 94:15437-15462.

Sager, W.W., and Pringle, M.S., 1988. Mid-Cretaceous to Early Tertiary apparent polar wander path of the Pacific Plate. J. Geophys. Res., 93:11753-11771.

Shackleton, N.J., Berger, A., and Peltier, W.R., 1990. An alternative astronomical calibration of the lower Pleistocene timescale based on ODP Site 677. Trans. R. Soc. Edinburgh, Earth Sci., 81:251-261.

Shipboard Scientific Party, 1975. Site 306: Shatsky Rise. In Larson, R.L., Moberly, R., et al., Init. Repts. DSDP, 32: Washington (U.S. Govt. Printing Office), 159-191.

Storms, M.A., Natland, J.H., et al., 1991. Proc. ODP, Init. Repts., 132: College Station, TX (Ocean Drilling Program).

Tauxe, L., Deino, A.D., Behrensmeyer, A.K., and Potts, R., 1992. Pinning down the Brunhes/Matuyama and upper Jaramillo boundaries: a reconciliation of orbital and isotopic time scales. Earth Planet. Sci. Lett., 109:561-572.

\footnotetext{
Abbreviations for names of organizations and publications in ODP reference lists follow the style given in Chemical Abstracts Service Source Index (published by American Chemical Society).
}

Date of initial receipt: 20 December 1992

Date of acceptance: 21 May 1993

Ms 132SR-304 